\title{
Postnatal changes in testicular gonadotropin receptors, serum gonadotropin, and testosterone concentrations and functional development of the testes in bulls
}

\author{
E T Bagu, S Cook, C L Gratton and N C Rawlings \\ Department of Veterinary Biomedical Sciences, Western College of Veterinary Medicine, University of Saskatchewan, \\ 52 Campus Drive, Saskatoon, Saskatchewan, Canada S7N 5B4
}

Correspondence should be addressed to NC Rawlings; Email: norman.rawlings@usask.ca

\begin{abstract}
The primary objectives of this study were to follow the temporal patterns of testicular LH and FSH receptor (LH-R and FSH-R) concentrations and affinity $\left(\mathrm{K}_{\mathrm{a}}\right)$ during sexual maturation in bulls and to see if such patterns could help explain the control of rapid testicular growth that occurs after 25 weeks of age, when serum gonadotropin concentrations are low. Separate groups of Hereford $\times$ Charolais calves $(n=6)$ were castrated every 4 weeks from 5 to 33 weeks of age and at 56 weeks of age. A week prior to castrations, from 5 to 33 weeks of age, blood was collected every $15 \mathrm{~min}$ for $10 \mathrm{~h}$. The transition from indifferent supporting cells to Sertoli cells in seminiferous tubules was rapid between 13 and 25 weeks and rapid testis growth occurred after 25 weeks of age. Serum LH and FSH concentrations were transiently elevated at 12 weeks of age $(P<0.05)$. LH-R concentrations decreased from 13 to 25 weeks of age and increased to 56 weeks of age $(P<0.05)$. LH-RK decreased from 9 to 17 weeks of age, increased to 29 weeks of age and declined to 33 weeks of age $(P<0.05)$. FSH-R concentrations declined from 17 to 25 weeks of age then increased to 56 weeks of age $(P<0.05)$. FSH-RK increased from 17 to 25 weeks of age $(P<0.05)$. High concentrations of gonadotropins and their receptors may be critical to initiate testis growth postnatally and support it after 25 weeks of age in the face of low serum gonadotropin concentrations.

Reproduction (2006) 132 403-411
\end{abstract}

\section{Introduction}

In bulls, puberty has been defined as the time when an ejaculate has at least $5.0 \times 10^{7}$ sperm and a $10 \%$ linear motility (Wolf et al. 1965). Age at puberty varies with breed: in Hereford bulls it occurs between 39 and 52 weeks of age, in Charolais bulls between 33 and 53 weeks of age, and in Holstein bulls between 39 and 41 weeks of age (Wolf et al. 1965, Killian \& Amann 1972, Lunstra et al. 1978). In bull calves, serum luteinizing hormone $(\mathrm{LH})$ concentrations are transiently increased between 4 and 25 weeks of age, with minimal or no subsequent increase prior to puberty (McCarthy et al. 1979, Amann et al. 1986, Wise et al. 1987, Evans et al. 1993, 1996). In developing bulls, the patterns of serum FSH concentrations are variable; with reports of no change with time (McCarthy et al. 1979), a slight increase in the early postnatal period (Rawlings \& Evans 1995, Aravindakshan et al. 2000), and an increase from 4 to 32 weeks of age (Amann \& Walker 1983). During the early rise in serum LH concentrations, serum testosterone concentrations are low, increasing markedly after 28 weeks of age and reaching adult concentrations by 40 weeks of age (Rawlings et al. 1972, 1978, Secchiari et al. 1976, Amann \& Walker 1983).

In males, there are two distinct populations of Leydig cells: fetal and adult Leydig cells, which differentiate from mesenchymal cells prenatally and postnatally respectively (Mendis-Handagama \& Ariyaratne 2001). In bull calves, it was suggested that the demise of fetal Leydig cells occurred during the early postnatal period (Hooker 1970). Amann (1983) suggested that the high frequency of $\mathrm{LH}$ pulses that occurred in bull calves after 4 weeks of age, initiated differentiation and maturation of adult Leydig cells from progenitor cells around 12-16 weeks of age, and a switch from androstenedione to testosterone secretion. The elevated intratesticular testosterone concentrations, following the onset of Leydig cell differentiation, may initiate differentiation of indifferent supporting cells to Sertoli cells; differentiation is restricted to the period of 16-28 weeks of age (McCarthy et al. 1979, Curtis \& Amann 1981, Amann 1983). Subsequent increases in serum testosterone concentrations after 
28 weeks of age probably reflect enhanced production by Leydig cells or increased Leydig cell numbers (Amann 1983). In bull calves, spermatogenesis is initiated as early as 16 weeks of age and the appearance of elongated spermatids in the seminiferous tubules at 32 weeks of age marks the initial achievement of complete spermatogenesis (Curtis \& Amann 1981). Rapid testicular growth that occurs after 25 weeks of age is, therefore, a reflection of the above changes. It is unclear whether the transient early postnatal increase in serum LH concentrations is sufficient to trigger rapid testicular development or how important the subsequent low levels of $\mathrm{LH}$ and FSH are. There could also be important regulatory changes in the testis itself from 25 weeks of age to puberty that are critical for rapid testicular growth (Amann et al. 1986, Wise et al. 1987, Evans et al. 1993, 1996, Rawlings \& Evans 1995).

During sexual development, an increase in testicular gonadotropin receptor (LH-R) concentrations was reported in rats (Purvis et al. 1977, Hardy et al. 1990, Shan \& Hardy 1992) and dogs (Inaba et al. 1994). In the latter, the increase coincided with rapid testicular growth. In rams, testicular $\mathrm{LH}-\mathrm{R}$ concentrations increase from 90 to 150 days of age (Yarney \& Sanford 1989). In the two studies with bulls, testes were either collected from one separate individual Norwegian red calf every 4 weeks from 12 to 32 weeks of age, and at 40,52, and 68 weeks of age (Sundby et al. 1984) or from Holstein calves at 1, 7, 14 , and 56 days of age $(n=5) ; 12$ weeks of age $(n=4)$ and 24 weeks of age $(n=3)$; however, no samples were collected during the period of rapid testicular growth or just prior to puberty (Dias \& Reeves 1982). In these studies, gonadotropin receptor concentrations decreased with age, while binding affinities remained the same. Sample size and timing precluded a careful examination of gonadotropin receptor changes around the time of the early postnatal increase in serum gonadotropin concentrations or the period of rapid testicular growth.

The objectives of the present study were to determine if changes in gonadotropin receptor concentrations and affinity were related to the early postnatal increase in serum $\mathrm{LH}$ and FSH concentrations, differentiation of Sertoli cells, the onset and progression of spermatogenesis, and the period of rapid testicular growth, which occurs while serum LH and FSH concentrations are low.

\section{Materials and Methods}

\section{Animals and experimental procedures}

Fifty-four spring-born, age matched ( \pm 3 days) bull calves (Hereford $\times$ Charolais) were divided into nine groups of six calves each. Calves were suckled at pasture until they were weaned at 26 weeks of age. After weaning, calves were kept in corrals and provided with water and a standard feed ration ad libitum (Evans et al. 1995). Calf body weights were measured bi-weekly until castration. All experimental procedures were done in accordance with the regulations of the Canadian Council for Animal Care.

\section{Blood and testes collection}

Separate groups of calves $(n=6)$ were castrated every 4 weeks from 5 to 33 weeks of age, and at 56 weeks of age. A week prior to castration, from 5 to 33 weeks of age, blood samples $(5 \mathrm{ml})$ were collected every $15 \mathrm{~min}$ for $10 \mathrm{~h}$ from the jugular vein by an i.v. catheter, starting at $0800 \mathrm{~h}$ (Evans et al. 1995). Blood samples were left to clot for at least $12 \mathrm{~h}$ at room temperature and then serum was harvested and frozen at $-20^{\circ} \mathrm{C}$ until assayed. At castration, the testes were weighed and a tissue sample from the mid section of the right testis of each bull was fixed in Helly's reagent $\left(\mathrm{HgCl}_{2}(70 \mathrm{~g} / \mathrm{l})\right.$ and $\mathrm{K}_{2} \mathrm{Cr}_{2} \mathrm{O}_{7}$ (25 g/l) (VWR International Ltd, Edmonton, Alta, Canada) were dissolved in warm distilled water and formaldehyde $(40 \%)$ was then added immediately prior to fixing the testis (VWR International Ltd)). The rest of the right and left testes were plunged into liquid nitrogen for approximately $20 \mathrm{~min}$ and stored at $-70{ }^{\circ} \mathrm{C}$ until homogenization.

\section{RIAs}

Serum $\mathrm{LH}$ and FSH concentrations were determined using previously validated double-antibody RIAs (Rawlings \& Evans 1995). The LH concentrations are expressed in terms of NIDDK-bLH4. Sensitivity of the LH assay, defined as the lowest concentration of $\mathrm{LH}$ capable of significantly displacing labeled LH from the antibody ( $t$-test), was $0.1 \mathrm{ng} / \mathrm{ml}$. Intra- or interassay coefficients of variation (CV values) for the $\mathrm{LH}$ assay were 7.1 and $8.6 \%$ or 12.7 and $11.9 \%$ for reference sera with $\mathrm{LH}$ concentrations of 0.4 or $0.8 \mathrm{ng} / \mathrm{ml}$ respectively. The sensitivity of the $\mathrm{FSH}$ assay was $0.1 \mathrm{ng} / \mathrm{ml}$ and concentrations are expressed in terms of USDA-bFSH-I1. Intra- or interassay $\mathrm{CV}$ values for the $\mathrm{FSH}$ assay were 6.4 and $5.7 \%$ or 17.5 and $18.8 \%$ for reference sera with FSH concentrations of 1.9 or $6.8 \mathrm{ng} / \mathrm{ml}$ respectively. Serum testosterone concentrations were determined in a single pool of samples collected from each intensive bleed using a commercial, double-antibody RIA kit (Coat A-Count total testosterone; Diagnostics Product Corporation, Los Angeles, CA, USA). The testosterone assay sensitivity was $0.04 \mathrm{ng} / \mathrm{ml}$. The intraassay CV values were $19.7,12.7$, and $6.6 \%$ for reference sera with testosterone concentrations of 1.2 , 2.7 , and $7.0 \mathrm{ng} / \mathrm{ml}$ respectively.

\section{Bovine testicular $\mathrm{LH}$ and $\mathrm{FSH}$ receptor membrane fractions}

A frozen section $(6 \mathrm{~g})$ from the right testis of each of the bull calves castrated at 4 weeks intervals from 5 to 33 weeks of age and at 56 weeks of age $(n=6$ per age 
group), was homogenized to obtain membrane fractions using a published procedure (Sairam 1978, Yarney \& Sairam 1991). The testicular parenchyma was weighed, diced, and homogenized at maximum speed for $2.5 \mathrm{~min}$, using a Brinkmann polytron (PT 10203500, Steinhofhalde 22, Switzerland) in $25 \mathrm{mM}$ Tris- $\mathrm{HCl}$ buffer, containing $100 \mathrm{mM}$ sucrose $(\mathrm{pH}$ 7.5). Five milliliters of buffer were used per gram of tissue. All procedures, unless otherwise indicated, were carried out at $4{ }^{\circ} \mathrm{C}$. The homogenate was centrifuged at $500 \boldsymbol{g}$ for $30 \mathrm{~min}$ and the supernatant decanted into a fresh polystyrene tube and recentrifuged at $39000 \mathrm{~g}$ for $1 \mathrm{~h}$. The pellet was resuspended in $25 \mathrm{mM}$ Tris- $\mathrm{HCl}$ buffer $(\mathrm{pH} 7.5)$, containing $10 \mathrm{mM} \mathrm{MgCl}$, at a concentration of $1 \mathrm{~g}$ original tissue per milliliter. Aliquots of these fractions were stored at $-70{ }^{\circ} \mathrm{C}$. Prior to assay, the membrane fractions were gently pulsed to obtain a uniform suspension. The protein concentration in the testicular membrane fractions was determined by a Bio-Rad Assay (Bio-Rad) using BSA as a standard.

\section{Radio-receptor assay}

The radio-receptor assay was a modification of published methods (Sairam 1978, Yarney et al. 1988, Yarney \& Sairam 1991). Bovine LH (USDA-bLH-I1) or FSH (NIDDK-AFP5332B) was iodinated $\left({ }^{125} \mathrm{I}\right.$ ) (Amersham Biosciences) using published methods (Sairam 1978, Yarney \& Sanford 1989). When $730 \mathrm{ng}{ }^{125} \mathrm{I}-\mathrm{bLH}$ and $491 \mathrm{ng}{ }^{125} \mathrm{I}$ bFSH were incubated with an excess of bovine testicular membrane preparations total binding ranged from 12 to $13.7 \%$ and 17 to $19 \%$ respectively. The specific activity of ${ }^{125} \mathrm{I}-\mathrm{bLH}$ or ${ }^{125} \mathrm{I}$-bFSH was 0.162 or $0.192 \mathrm{mCi} / \mu \mathrm{g}$ respectively. To determine the affinity constant $\left(K_{\mathrm{a}}\right)$ and receptor concentrations by Scatchard analysis, three serial dilutions of $120 \pm 2,243 \pm 3$, and $364 \pm 4 \mathrm{CPM} / \mu \mathrm{l}$ of ${ }^{125} \mathrm{I}-\mathrm{bLH}$ (USDA-bLH-I1) and $99 \pm 2$, $194 \pm 1$, and $291 \pm 2 \mathrm{CPM} / \mu \mathrm{l}$ of ${ }^{125} \mathrm{I}-\mathrm{bFSH}$ (NIDDKAFP5332B) were used in the assay with each testicular homogenate. All incubations for the radio-receptor assays were done in triplicate in borosilicate glass test tubes $(12 \times 75 \mathrm{~mm}$; VWR, West Chester, PA 19380 , USA). To determine the total binding, $300 \mu$ l of ${ }^{125} \mathrm{I} \mathrm{bLH}$ or ${ }^{125} \mathrm{I} \mathrm{bFSH}$ was added to $100 \mu \mathrm{l}$ of testicular membrane fractions, the volume was made-up to $500 \mu \mathrm{l}$ with $100 \mu \mathrm{l}$ buffer $(25 \mathrm{mM}$ Tris- $\mathrm{HCl}$ buffer $(\mathrm{pH} 7.5)$, containing $10 \mathrm{mM} \mathrm{MgCl}$ and $0.1 \% \mathrm{BSA}$ ). In order to determine the non-specific binding (NSB) for each of the testicular membrane fractions, $100 \mu \mathrm{l}$ buffer containing $1500 \mathrm{ng}$ non-radiolabeled bLH or bFSH was added. Specific binding was defined as the difference between the total binding and NSB and was approximately $37 \pm 3$ and $61 \pm 1 \%$ of total binding for $\mathrm{LH}$ and $\mathrm{FSH}$ respectively. The assays were incubated $24 \mathrm{~h}$ at $4{ }^{\circ} \mathrm{C}$. Incubation was terminated by adding $2.5 \mathrm{ml}$ of $25 \mathrm{mM}$ Tris-HCl buffer (pH 7.5, containing $10 \mathrm{mM} \mathrm{MgCl} 2,0.1 \% \mathrm{BSA}$ and $8 \%$ polyethylene glycol) and test tubes were immediately centrifuged at $4000 \boldsymbol{g}$ for $25 \mathrm{~min}$ in a Beckman JS-5.2 Rotor (Beckman Instruments, Inc., Palo Alto, CA, USA). The supernatant was decanted and the radioactivity in the pellet determined using a gamma counter (efficiency 80\%; Apex gamma counter, Titertek Instruments, Inc., Huntsville, AL, USA). Affinity constants $\left(K_{\mathrm{a}}\right)$ and binding capacities were determined by analyzing the binding data using a non-linear regression analysis or Scatchard analysis (Sigma Stat for Windows, version 1.0; Jadel Corporation, San Rafael, CA, USA) similar to Munson \& Rodbard (1980). After the ratio of receptor bound radiolabeled hormone to free radiolabeled hormone $(\mathrm{B} / \mathrm{F})$ was plotted against the receptor bound radiolab eled hormone (B), a non-linear curve was fitted to determine the slope or the binding affinity $\left(K_{\mathrm{a}}\right)$ and $x$-intercept (binding capacity). The receptor concentrations were then expressed as moles per milligram of protein (specific binding capacity). The interassay CV for the binding capacity and $K_{\mathrm{a}}$ were determined by replicating pooled testicular membrane fractions collected at 56 weeks of age, in all assays, as an internal control. The interassay CV for LH-R with a mean specific binding capacity and $K_{\mathrm{a}}$ of $4.8 \pm 0.5 \mathrm{pM} / \mathrm{mg}$ protein and $1.82 \pm 0.1 \times 10^{-10} \mathrm{M}^{-1}$ were 16.2 and $13.5 \%$ respectively. The interassay $\mathrm{CV}$ for FSH-R with a mean specific $b$ inding capacity and $K_{\mathrm{a}}$ of $9.8 \pm 0.7 \mathrm{pM} / \mathrm{mg}$ protein and $2.0 \pm 0.1 \times 10^{-10} \mathrm{M}^{-1}$, were 12.8 and $7.4 \%$ respectively.

In the bovine LH-R assay, 21 or $45 \%$ displacement of ${ }^{125} \mathrm{I}$-bLH was caused by 10 or $100 \mathrm{ng}$ of bLH per tube (USDA-bLH-I1) respectively. No displacement was seen with $100 \mathrm{ng}$ of either bovine prolactin (AFP 4835b) or bovine growth hormone (bGH AFP 11182B); however, $100 \mathrm{ng} /$ tube of bovine FSH (USDA-bFSH-I-1) and bovine TSH (NIADDK bTSH I3) caused 14 and 16\% displacement respectively. In the bovine FSH-R assay, 30 or $51 \%$ displacement of ${ }^{125} \mathrm{I}$ bFSH was caused by 10 or $100 \mathrm{ng}$ of bFSH/tube respectively (USDA-bFSH-I-1). No displacement was seen with $100 \mathrm{ng}$ of either bovine prolactin (AFP 4835b) or bovine growth hormone (bGH AFP 11182B); however, $100 \mathrm{ng} /$ tube of bovine LH (USDAbLH-I1) and bovine TSH (NIADDK bTSH I3) caused 24 and $23 \%$ displacement respectively.

\section{Histology}

Sections of testicular parenchyma were stored in Helly's reagent for $24 \mathrm{~h}$, rinsed in water for $48 \mathrm{~h}$, washed in $70 \%$ ethanol, then dehydrated in alcohol and embedded in paraffin wax. A $5 \mu \mathrm{m}$ thick section from each of the bull calves castrated at 4 week intervals from 5 to 33 weeks of age and at 56 weeks of age ( $n=6$ per age group) was stained with hemotoxylin and periodic acid Schiff's (H-PAS) and evaluated for development of spermatogenesis. A systematic, uniform, random sampling technique as described by Curtis \& Amann (1981) and Evans et al. (1995), was used to select 20 round seminiferous tubules 
in the section from each bull. In each seminiferous tubule, at $1000 \times$ magnification, Sertoli cells and their progenitor indifferent supporting cells were enumerated and the most mature germ cell identified; the tubule was classified according to the most mature germ cell in it. This classification was based on a scheme of seven groups of germ cell types: (1) gonocytes, (2) prespermatogonia, (3) A- and B-spermatogonia, (4) primary spermatocytes, (5) secondary spermatocytes, (6) round spermatids, and (7) elongating spermatids. The percentage of tubules with a particular germ cell type as the most mature germ cell was determined by multiplying the number of seminiferous tubules with a particular germ cell type as the most mature germ cell by $100 \%$ and then dividing the product by 20 (the total number of seminiferous tubules evaluated from the section of each bull). Sertoli cells and their precursor cells were only evaluated in sections collected from at 5, 13, 21, 25, 33, and 56 weeks of age. Testicular germ cells and somatic cells were identified according to published descriptions (Berndston \& Desjardins 1974, Curtis \& Amann 1981). All the histological evaluations were done by a single operator in a random order without knowledge of the age groups.

\section{Data analysis}

Serum LH and FSH secretory characteristics in blood samples collected every $15 \mathrm{~min}$ for $10 \mathrm{~h}$ were determined by the PC-pulsar program (J Gitzen and V Ramirez, University of Illinois, Urbana, IL, USA). Serum LH pulse frequency and amplitude as well as basal and mean serum concentrations are presented. The secretory patterns of FSH were judged to be non-pulsatile, therefore mean concentrations are presented. The LH pulses were defined using S.D. criteria of height ( $G$ values) and duration (Merriam \& Wachter 1982). Data for LH pulse amplitude, $\mathrm{LH}$ pulse frequency, basal and mean LH concentrations, mean FSH concentrations, mean testosterone concentrations, testicular weight, testicular gonadotropin receptor concentration per milligram of protein, gonadotropin receptor $K_{\mathrm{a}}$, the percentage distribution of the most mature germ cell in each of the 20 seminiferous tubules, indifferent supporting cell counts per seminiferous tubule, Sertoli cell counts per seminiferous tubule, and body weight were analyzed for effects of age by one-way ANOVA (one-ANOVA, Sigma Stat for Windows, version 1.0; Jadel Corporation, San Rafael, CA, USA). If main effects were significant, paired comparisons were made using the Fisher's least significant difference method for postANOVA multiple comparisons $(P<0.05)$. Pearson correlations were used to examine the relationships between mean serum LH concentrations, serum LH pulse frequency, mean serum FSH concentrations, mean serum testosterone concentrations, testicular LH-R concentrations, LH-R affinity constant, testicular FSH-R concentrations, testicular FSH-R affinity constant, testicular weight, indifferent supporting cell counts per seminiferous tubule, and Sertoli cell counts per seminiferous tubule.

\section{Results \\ Body weights and testicular growth}

Mean body weight increased from 5 to 21 weeks of age and from 25 to 29 weeks of age then subsequently from 33 to 56 weeks of age $(P<0.05$; Fig. 1$)$. Mean testicular weight increased from 9 to 21 weeks of age and then from 25 to 56 weeks of age $(P<0.01$; Fig. 1$)$.

\section{Hormonal patterns}

Mean serum LH concentrations increased from 4 to 12 weeks of age then declined to 20 weeks of age $(P<0.05$; Fig. 2a). Basal serum LH concentrations increased from 8 to 12 weeks of age then declined to 16 weeks of age $(P<0.05$; Fig. 2b). The LH pulse frequency increased from 4 to 12 weeks of age then declined to 16 weeks of age ( $P<0.05 ;$ Fig. $2 \mathrm{C})$. The $\mathrm{LH}$ pulse amplitude declined from 24 to 28 weeks of age $(P<0.05$; Fig. 2 d). Mean serum FSH concentrations declined from 12 to 20 weeks of age $(P<0.05 ;$ Fig. 3). Mean serum testosterone concentrations increased from 8 to 20 weeks of age, declined to 28 weeks of age and then subsequently increased from 28 to 32 weeks of age $(P<0.01$; Fig. 4).

\section{Testicular gonadotropin receptor patterns}

The mean testicular LH-R concentrations (picomolar per milligram of protein) decreased from 13 to 25 weeks of age and then increased to 56 weeks of age $(P<0.05$; Fig. 5a). Mean testicular LH-R concentrations (picomolar per milligram of protein) were positively correlated with $\mathrm{LH}$ pulse frequency and mean serum concentrations of $\mathrm{LH}$ and FSH $(P<0.05 ; r$-values of $0.47,0.51$, and 0.51 respectively). Testicular $\mathrm{LH}^{-\mathrm{RK}} \mathrm{a}_{\mathrm{a}}$ decreased from 9 to 17 weeks of age, increased to 29 weeks of age and then declined to 33 weeks of age ( $P<0.05$; Fig. 5b). Testicular $\mathrm{LH}^{-\mathrm{RK}_{a}}$ was negatively correlated with mean serum LH concentrations, LH pulse amplitude, and mean testicular LH-R concentrations (picomolar/milligram of protein; $P<0.05$; $r$-values $-0.32,-0.32$, and -0.31 respectively). The mean testicular FSH-R concentrations (picomolar/milligram of protein) declined from 17 to 25 weeks of age then increased to 56 weeks of age $(P<0.05$; Fig. 6a). Mean testicular FSH-R concentrations (picomolar/milligram of protein) were positively correlated with mean testicular LH-R concentrations (picomolar/milligram of protein) and mean testicular weight $(P<0.05 ; r$-values of 0.53 and 0.63 respectively). The

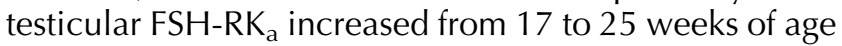
$\left(P<0.05\right.$; Fig. 6b). Testicular $\mathrm{FSH}_{-} \mathrm{RK}_{\mathrm{a}}$ was positively correlated with mean testicular weight $(P<0.05 ; r$-value 

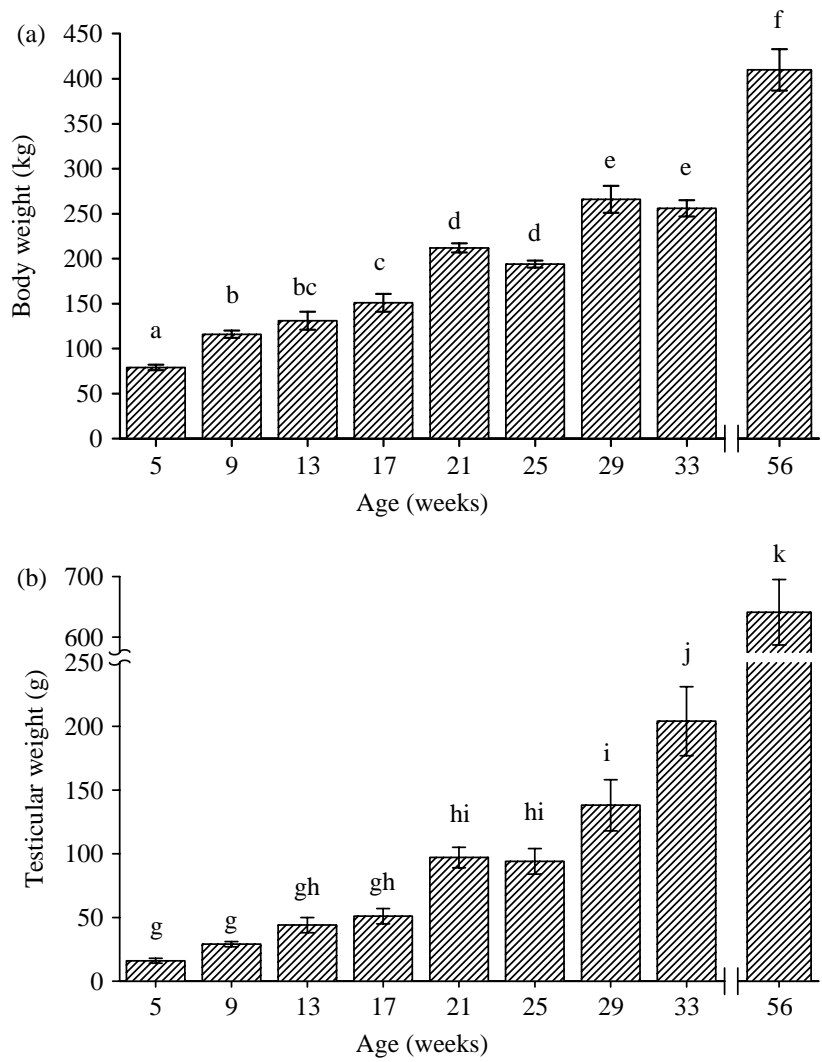

Figure 1 Mean ( \pm S.E.M.) (a) body weight and (b) testicular weight of bull calves. Separate groups of bull calves $(n=6)$ were weighed and then castrated at 4 weeks intervals from 5 to 33 weeks of age and at 56 weeks of age. The testes (right and left) were weighed at castration. The differences between ages within variables are indicated by different superscripts $(P<0.05)$.

0.4); however, it was negatively correlated with mean testicular FSH-R concentrations (picomolar/milligram of protein), from 5 to 33 weeks of age $(P<0.01 ; r-0.43)$.

\section{Sertoli cell development}

The mean indifferent supporting cell (immature Sertoli cell) count per seminiferous tubule decreased from 13 to 33 weeks of age $(P<0.05$; Fig. 7$)$. As the indifferent supporting cells differentiated into mature Sertoli cells, the mean Sertoli cell count per seminiferous tubule increased from 13 to 33 weeks of age $(P<0.05$; Fig. 7$)$.

\section{Germ cell development}

The percentage of seminiferous tubules with gonocytes as the most mature germ cell type decreased from 5 to 13 weeks of age and from 17 to 21 weeks of age $(P<0.01$; Table 1$)$. The percentage of seminiferous tubules with pre-spermatogonia as the most mature germ cell type decreased from 5 to 9 weeks of age and from 17 to 21 weeks of age $(P<0.01)$. The percentage of seminiferous tubules with A- and B-spermatogonia as
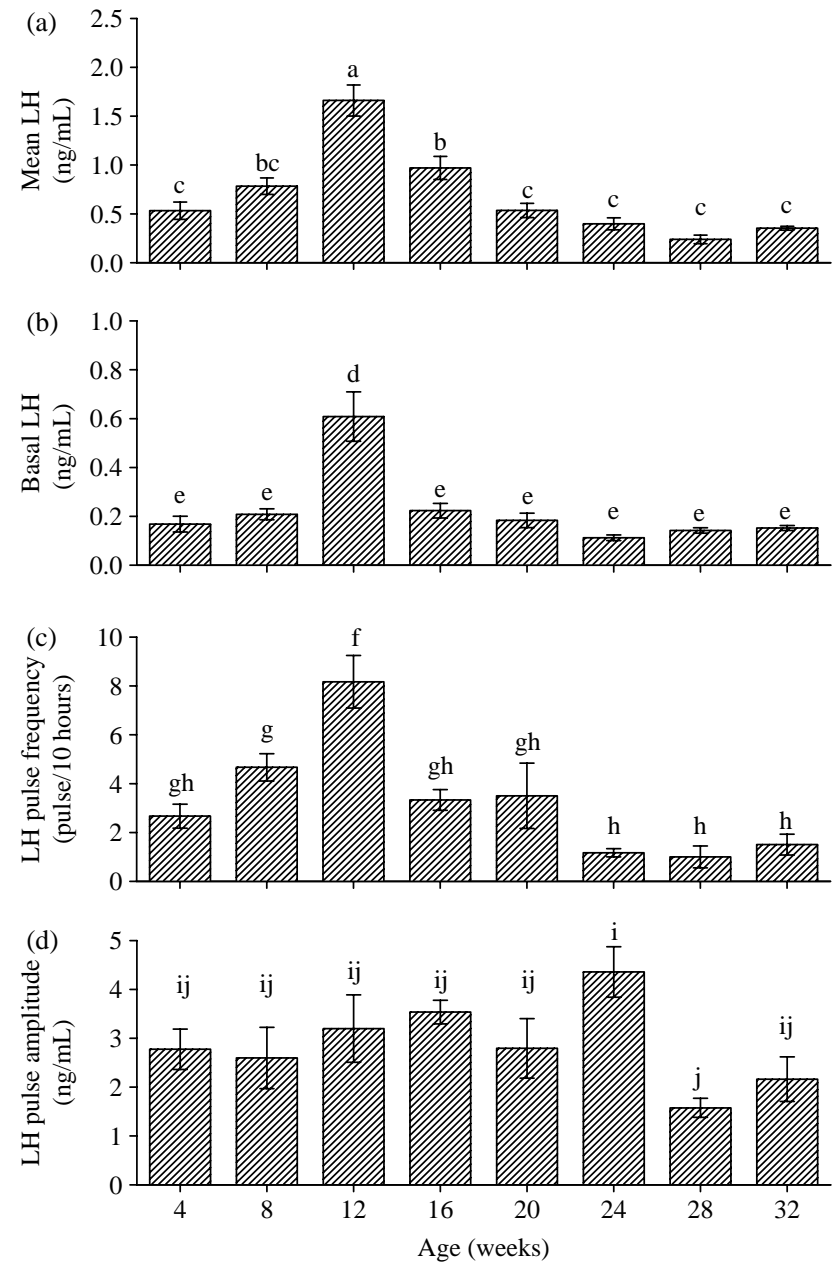

Figure 2 Mean ( \pm S.E.M.) (a) serum LH concentrations, (b) basal LH concentrations, (c) LH pulse frequency, and (d) LH pulse amplitude in blood samples collected every $15 \mathrm{~min}$ for $10 \mathrm{~h}$, at 4 weeks intervals from 4 to 32 weeks of age, from separate groups of calves $(n=6)$. The differences between ages within variables are indicated by different superscripts $(P<0.05)$.

the most mature germ cell type increased from 5 to 13 weeks of age and decreased from 13 to 25 weeks of age $(P<0.01$; Table 1$)$. The percentage of seminiferous tubules with primary spermatocytes as the most mature germ cell type increased from 17 to 25 weeks of age and then decreased from 33 to 56 weeks of age $(P<0.01$; Table 1$)$. The percentage of seminiferous tubules with secondary spermatocytes as the most mature germ cell type increased from 21 to 25 weeks of age $(P<0.01$; Table 1$)$. The percentage of seminiferous tubules with round spermatids as the most mature germ cell type increased from 21 to 25 weeks of age and from 29 to 33 weeks of age, then subsequently decreased from 33 to 56 weeks of age $(P<0.01$; Table 1). The percentage of seminiferous tubules with elongated spermatids as the most mature germ cell type increased from 21 to 25 weeks of age and from 33 to 56 weeks of age $(P<0.01$; Table 1$)$. 


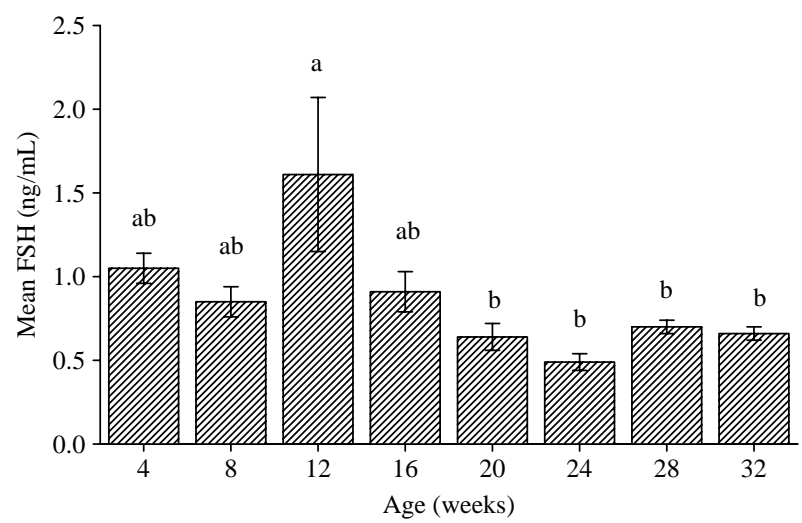

Figure 3 Mean ( \pm S.E.M.) serum FSH concentrations in blood samples collected every $15 \mathrm{~min}$ for $10 \mathrm{~h}$, at 4 weeks intervals from 4 to 32 weeks of age from separate groups of calves $(n=6)$. The differences between ages are indicated by different superscripts $(P<0.05)$.

\section{Discussion}

In the present study, between 4 and 25 weeks of age, serum concentrations of $\mathrm{LH}$ and $\mathrm{FSH}$ were transiently elevated confirming previous reports (Wise et al. 1987, Evans et al. 1993, 1996, Aravindakshan et al. 2000). As was previously suggested, the early postnatal increase in $\mathrm{LH}$ secretion, noted in the present study, was caused by an increase in LH pulse frequency (McCarthy et al. 1979, Amann \& Walker 1983, Evans et al. 1993, 1996). It is probable that the high frequency discharge of $\mathrm{LH}$ between 4 and 25 weeks of age influenced Leydig cell differentiation and maturation, and led to increased secretion of testosterone after 12 weeks of age (Rawlings et al. 1972, 1978, Secchiari et al. 1976, Amann 1983, Amann \& Walker 1983, Rawlings \& Cook 1986, Mendis-Handagama \& Ariyaratne 2001). The marked increase in mean serum testosterone concentrations from 16 to 20 weeks of age, noted in the present study, probably terminated the early postnatal increase in

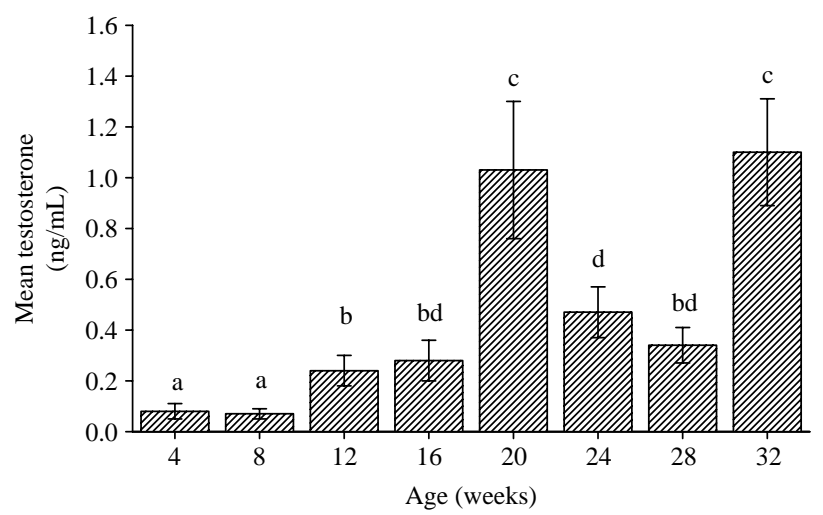

Figure 4 Mean ( \pm S.E.M.) serum testosterone concentrations in pooled blood samples collected every $15 \mathrm{~min}$ for $10 \mathrm{~h}$, at 4 weeks intervals from 4 to 32 weeks of age from separate groups of calves $(n=6)$. The differences between ages are indicated by different superscripts $(P<0.05)$.
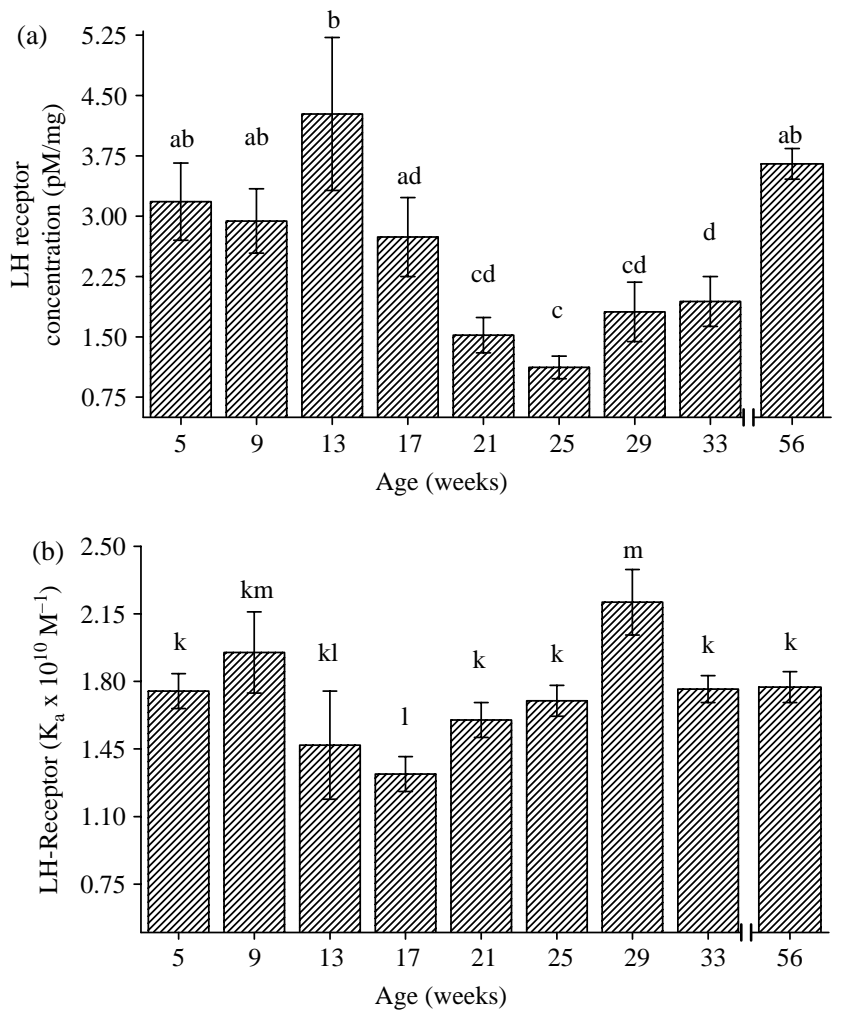

Figure 5 Mean ( \pm S.E.M.) (a) testicular luteinizing hormone receptor (LH-R) concentrations per milligram of protein; (b) testicular LH-R affinity $\left(K_{\mathrm{a}}\right)$ for samples collected from separate groups of bull calves $(n=6)$ castrated at 4 weeks intervals from 5 to 33 weeks of age and at 56 weeks of age. The differences between ages within variables are indicated by different superscripts $(P<0.05)$.

serum concentrations of $\mathrm{LH}$ and FSH (Rawlings et al. 1978, Evans et al. 1995).

In males, there are two distinct populations of Leydig cells: fetal and adult Leydig cells, which differentiate from mesenchymal cells prenatally and postnatally respectively (Mendis-Handagama \& Ariyaratne 2001). In bull calves, it was suggested that the demise of fetal Leydig cells occurred during the early postnatal period (Hooker 1970). Differentiation and maturation of adult Leydig cells in bulls is initiated around weeks 12-16 and continues actively up to 28 weeks of age (Amann 1983). This phase of differentiation and maturation would appear to be reflected in the increased testosterone production from 8 to 20 weeks of age in the present study. Amann (1983) suggested that in bull calves the enhanced testosterone production after 28 weeks of age involved increased cellular synthesis or increased Leydig cell numbers. The peaks in testosterone production seen at 20 and 32 weeks of age in the present study, with the intervening trough, have previously been noted (Rawlings et al. 1972, 1978, Secchiari et al. 1976). Progenitor Leydig cells and Leydig cells resident in the testicular interstitium are the target cells for $\mathrm{LH}$ action (Shanbacher 1979, Mendis-Handagama \& Ariyaratne 

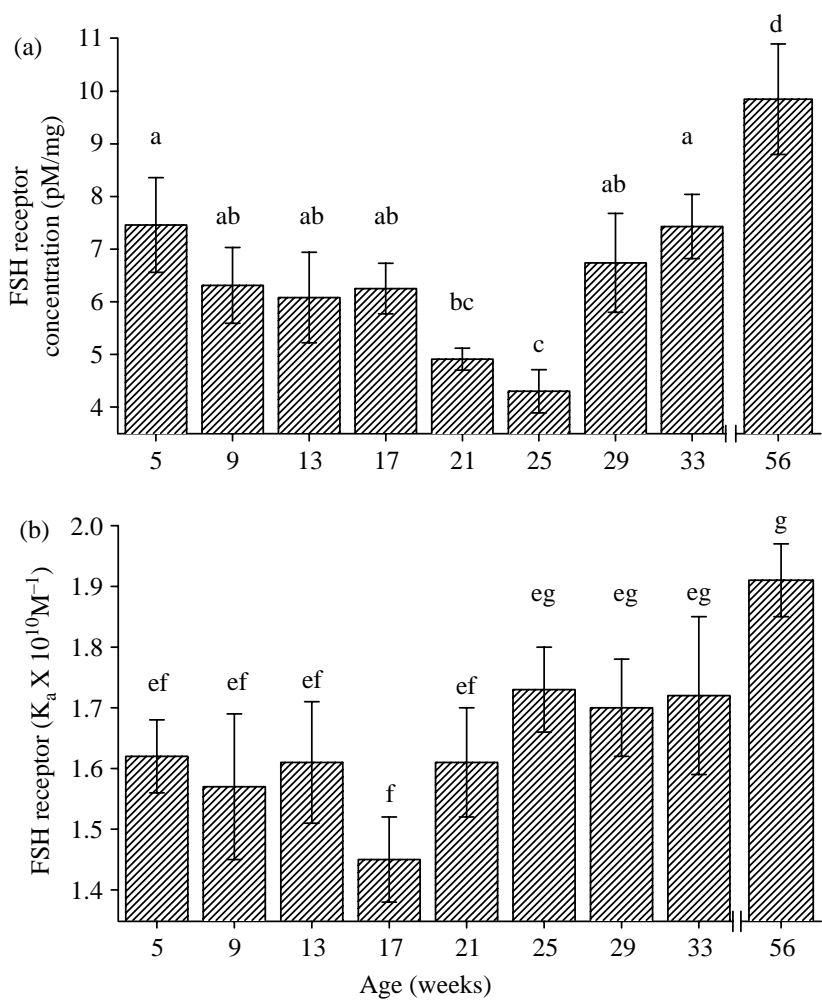

Figure 6 Mean ( \pm S.E.M.) (a) testicular follicle stimulating hormone receptor ( $\mathrm{FSH}-\mathrm{R})$ concentration per milligram of protein; (b) testicular FSH-R affinity $\left(K_{\mathrm{a}}\right)$ for samples collected from separate groups of bull calves $(n=6)$ castrated at 4 weeks interval from 5 to 33 weeks of age and at 56 weeks of age. The differences between ages within variables are indicated by different superscripts $(P<0.05)$.

2001). In the present study, the high concentrations of testicular LH-R in the early postnatal calves and the decline in concentrations from 13 to 21 weeks of age probably reflected high numbers of fetal Leydig cells and undifferentiated Leydig progenitor cells followed by a decline in numbers of both. It is interesting that as adult

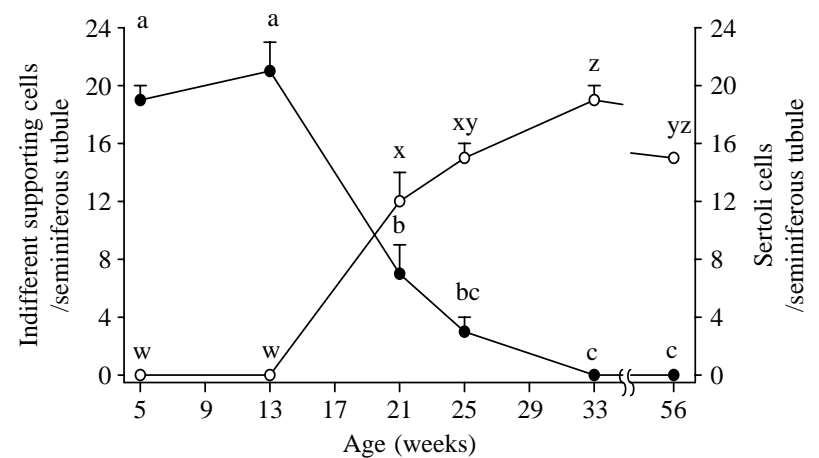

Figure 7 Mean ( \pm s.E.M.) Sertoli cell numbers (open circles) and their progenitor indifferent supporting cells (solid circles) per section of seminiferous tubule. Twenty randomly selected tubules were examined from one testis per bull at $1000 \times$ magnification. Counts were done for separate groups of bull calves $(n=6)$ castrated at 5, 13, 21, 25, 33, and 56 weeks of age. The differences between ages within variables are indicated by different superscripts $(P<0.05)$.
Leydig cells differentiated and matured, as reflected in enhanced testosterone production from 8 to 20 weeks of age, testicular LH-R concentrations declined but LH-RKa was maintained. However, the early postnatal increase in mean serum $\mathrm{LH}$ concentrations rising to a peak at 12 weeks of age is clearly positioned to initiate the differentiation and maturation of adult Leydig cells. At least LH drives the latter stages of Leydig cell differentiation in rats, mice, and humans (MendisHandagama \& Ariyaratne 2001). It is likely that the increases seen in LH-R concentration in the testis beyond 25 weeks of age, in the present study, especially at 56 weeks of age, reflected further Leydig cell maturation or increased numbers of Leydig cells as suggested by Amann (1983). In the present study, the positive correlation of testicular LH-R concentrations with testicular FSH-R concentrations suggested FSH affected Leydig cell development, acting via Sertoli cells. Administration of FSH to in vitro co-cultured purified pig Leydig and Sertoli cells increased Leydig cell LH/ human choriogonadotropin binding sites and their capacity to secrete testosterone (Tabone et al. 1984). In the present study, LH-R concentrations increased from 25 to 56 weeks of age along with the Leydig cell testosterone production.

In the present study, the high mean testicular FSH-R concentrations from 5 to 13 weeks of age were probably a result of the high number of indifferent supporting cells per seminiferous tubule (Curtis \& Amann 1981). In bull calves, indifferent supporting cells and Sertoli cells resident in the seminiferous tubules are the target cells for FSH action (Shanbacher 1979). The drop in mean testicular FSH-R concentrations from 17 to 25 weeks of age accompanied the precipitous decline in numbers of indifferent supporting cells as they differentiated into mature Sertoli cells and may have also been influenced by the rapid onset of spermatogenesis, particularly increased spermatocytes. The latter would have effectively decreased $\mathrm{FSH}-\mathrm{R}$ concentrations per $\mathrm{mg}$ of protein. The increase in testicular FSH-R concentrations from 25 to 56 weeks of age was probably due to maturation of the immature Sertoli cells. In bull calves, it was suggested that testosterone stimulates the differentiation of indifferent supporting cells (immature Sertoli cells) to mature Sertoli cells (Amann 1983).

In the present study, mean serum FSH concentrations and FSH-R concentrations were high when the seminiferous tubules were occupied primarily by immature germ cells (gonocytes and prespermatogonia). This may have facilitated the FSH-dependent proliferation and differentiation of the immature germ cells to primary spermatocytes (Means et al. 1976, Amann 1983, Jegou et al. 1983). In the present study, the percentage of seminiferous tubules with secondary spermatocytes as the most mature germ cell increased from 21 to 25 weeks of age and coincided with the period of low serum LH concentrations and testicular LH-R concentrations, from 
Table 1 Mean ( \pm s.E.M.) percentage of seminiferous tubules with a particular germ cell type as the most mature germ cell (gonocytes, prespermatogonia, A- and B-spermatogonia, primary spermatocytes, secondary spermatocytes, round spermatids, and elongating spermatids) in 20 randomly selected round seminiferous tubules per histological section of testis samples collected from separate groups of bull calves ( $n=6)$ castrated at 4 weeks intervals from 5 to 33 weeks of age and at 56 weeks of age.

\begin{tabular}{|c|c|c|c|c|c|c|c|}
\hline $\begin{array}{l}\text { Age } \\
\text { (weeks) }\end{array}$ & Gonocytes & Pre-spermatogonia & $\begin{array}{c}\text { A- and B- } \\
\text { spermatogonia }\end{array}$ & $\begin{array}{c}\text { Primary } \\
\text { spermatocytes }\end{array}$ & $\begin{array}{c}\text { Secondary } \\
\text { spermatocytes }\end{array}$ & $\begin{array}{c}\text { Rounded } \\
\text { spermatids }\end{array}$ & $\begin{array}{c}\text { Elongated } \\
\text { spermatids }\end{array}$ \\
\hline 5 & $41 \pm 5^{\mathrm{a}}$ & $49 \pm 4^{\mathrm{a}}$ & $10 \pm 3^{\mathrm{a}}$ & $0 \pm 0^{\mathrm{a}}$ & $0 \pm 0^{a}$ & $0 \pm 0^{a}$ & $0 \pm 0^{a}$ \\
\hline 9 & $31 \pm 2^{b}$ & $29 \pm 5^{b}$ & $36 \pm 4^{b}$ & $2 \pm 1^{a}$ & $0 \pm 0^{\mathrm{a}}$ & $0 \pm 0^{\mathrm{a}}$ & $0 \pm 0^{\mathrm{a}}$ \\
\hline 13 & $13 \pm 4^{\mathrm{cd}}$ & $32 \pm 4^{\mathrm{b}}$ & $51 \pm 4^{c}$ & $3 \pm 3^{a}$ & $0 \pm 0^{a}$ & $0 \pm 0^{\mathrm{a}}$ & $0 \pm 0^{a}$ \\
\hline 17 & $19 \pm 6^{\mathrm{d}}$ & $27 \pm 6^{\mathrm{b}}$ & $38 \pm 9^{\mathrm{bc}}$ & $15 \pm 6^{a}$ & $0 \pm 0^{a}$ & $0 \pm 0^{a}$ & $0 \pm 0^{a}$ \\
\hline 21 & $5 \pm 3^{\mathrm{ce}}$ & $6 \pm 2^{\mathrm{c}}$ & $35 \pm 13^{\mathrm{bcd}}$ & $37 \pm 15^{\mathrm{ab}}$ & $0 \pm 0^{\mathrm{a}}$ & $0 \pm 0^{\mathrm{a}}$ & $0 \pm 0^{a}$ \\
\hline 25 & $2 \pm 1^{\mathrm{e}}$ & $1 \pm 1^{\mathrm{c}}$ & $18 \pm 12^{\mathrm{ad}}$ & $40 \pm 11^{b}$ & $8 \pm 4^{\mathrm{bc}}$ & $18 \pm 8^{\mathrm{b}}$ & $14 \pm 7^{b}$ \\
\hline 29 & $0 \pm 0^{\mathrm{e}}$ & $0 \pm 0^{c}$ & $13 \pm 6^{\mathrm{a}}$ & $50 \pm 8^{\mathrm{b}}$ & $9 \pm 3^{b c}$ & $18 \pm 7^{b}$ & $9 \pm 5^{b}$ \\
\hline 33 & $0 \pm 0^{\mathrm{e}}$ & $0 \pm 0^{c}$ & $6 \pm 6^{\mathrm{a}}$ & $44 \pm 9^{b}$ & $3 \pm 2^{a b}$ & $31 \pm 7^{c}$ & $17 \pm 9^{b}$ \\
\hline 56 & $0 \pm 0^{e}$ & $0 \pm 0^{c}$ & $0 \pm 0^{a}$ & $0 \pm 0^{a}$ & $3 \pm 3^{a b}$ & $18 \pm 3^{b}$ & $76 \pm 6^{c}$ \\
\hline
\end{tabular}

The differences between ages within columns are indicated by different superscripts $a, b$, and c $(P<0.05)$.

20 to 33 weeks of age. In the present study, the $\mathrm{LH}$-dependent release of testosterone, essential for the progression of primary spermatocytes to secondary spermatocytes, could have been facilitated by the increased $\mathrm{LH}^{-\mathrm{RK}_{\mathrm{a}}}$ noted from 21 to 29 weeks of age (Purvis et al. 1977). In the present study, elongated and rounded spermatids were the most mature germ cells in the seminiferous tubules between 25 and 33 weeks of age, during the period of high serum testosterone concentrations. A similar association between stages VII and VIII of spermatogenesis and elevated serum testosterone was seen in rats (Pearson \& Tubbes 1967). In the present study, during the period of increase in the percentage of seminiferous tubules with elongated spermatids as the most mature germ cell type, from 29 to 56 weeks of age, mean serum FSH concentrations were low but testicular FSH-RK ${ }_{a}$ and FSH-R concentrations were high. This implied that the increased Sertoli cell sensitivity to FSH ensured the progression and sustenance of spermatogenesis during low serum FSH concentrations (Means et al. 1976, Amann 1983, Jegou et al. 1983, Orth 1984).

In the present study, a rapid increase in testicular weight occurred after 25 weeks of age and coincided with increased serum testosterone concentrations, gonadotropin receptor concentrations and affinity. It is likely that testicular growth was initiated by the high postnatal serum gonadotropin concentrations and testicular gonadotropin receptor concentrations and was maintained by the increased sensitivity of the Sertoli and Leydig cells to low serum FSH and LH concentrations respectively as reported for the ram (Yarney \& Sanford 1989) and rat (Dufau \& Catt 1978). The increase in gonadotropin receptor concentrations from 25 to 56 weeks of age differs from previous reports in bull calves (Dias \& Reeves 1982, Sundby et al. 1984); however, low sample number and lack of sampling during the period of rapid testicular growth and just prior to puberty could have confounded trends in those studies.
We concluded that high concentrations of serum gonadotropins and testicular gonadotropin receptors during the early postnatal period in bull calves may be critical to the initiation of rapid testis growth; however, increased gonadotropins receptor concentrations and affinity in the face of low circulating gonadotropin concentration and high testosterone concentrations may support rapid testicular growth after 25 weeks of age. The high testicular gonadotropin receptor concentration and affinity during low serum gonadotropin concentrations suggested a high Leydig and Sertoli cell sensitivity to low serum $\mathrm{LH}$ and FSH concentrations respectively.

\section{Acknowledgements}

This research was funded by the Natural Sciences and Engineering Research Council of Canada and the Saskatchewan Agricultural Development Fund (NC Rawlings). ET Bagu was supported by a University of Saskatchewan graduate studies and research scholarship. The authors thank $R$ Duggavathi and DM Barrett for their help in blood sampling, B Kerr and his staff for the care and management of the animals, NIDDK and USDA for provision of assay reagents and SIOUX Biochemicals for gonadotropin preparations. The authors declare that there is no conflict of interest that would prejudice the impartiality of this scientific work.

\section{References}

Amann RP 1983 Endocrinological changes associated with onset of spermatogenesis in Holstein bulls. Journal of Dairy Science $\mathbf{6 6}$ 2606-2622.

Amann RP \& Walker OA 1983 Changes in pituitary-gonadal axis associated with puberty in Holstein bulls. Journal of Animal Science 57 422-433.

Amann RP, Wise WE, Glass JD \& Nett TM 1986 Prepubertal changes in the hypothalamic pituitary in Holstein bulls. Biology of Reproduction 34 71-80.

Aravindakshan JP, Honaramooz A, Bartlewski PM, Beard AP, Pierson RA \& Rawlings NC 2000 Gonadotropin secretion in prepubertal bull calves born in spring and autumn. Journal of Reproduction and Fertility 120 159-167. 
Berndston WE \& Desjardins C 1974 The cycle of the seminiferous epithelium and spermatogenesis in the bovine testis. American Journal of Anatomy 140 167-179.

Curtis SK \& Amann RP 1981 Testicular development and establishment of spermatogenesis in Holstein bulls. Journal of Animal Science $\mathbf{5 3}$ 1645-1657.

Dias JA \& Reeves JJ 1982 Testicular FSH receptor numbers and affinity in bulls of various ages. Journal of Reproduction and Fertility $\mathbf{6 6}$ $39-45$.

Dufau ML \& Catt KJ 1978 Gonadotropin receptors and regulation of steroidogenesis in the testis and ovary. Vitamins and Hormones $\mathbf{3 6}$ 461-592.

Evans ACO, Currie WD \& Rawlings NC 1993 Opioidergic regulation of gonadotropin secretion in the early prepubertal calf. Journal of Reproduction and Fertility 99 45-51.

Evans ACO, Davis FJ, Nasser LF, Bowman P \& Rawlings NC 1995 Differences in early patterns of gonadotropin secretion between early and late maturing bulls and changes in semen characteristics at puberty. Theriogenology 43 569-578.

Evans ACO, Pierson RA, Garcia A, McDougall LM, Hrudka F \& Rawlings NC 1996 Changes in circulating hormone concentrations, testes histology and testes ultrasonography during sexual maturation in beef bulls. Theriogenology 46 345-357.

Hardy MP, Kelce WR, Klinefelter GR \& Ewing LL 1990 Differentiation of Leydig cell precursors in vitro: a role for androgen. Journal of Endocrinology 127 488-490.

Hooker CW 1970 The intertubular tissue of the testis. Life history of the Leydig cells. In The Testis, 1 edn, pp 488-490. Eds AD Johnson, WR Gomes \& NL VanDenmark. New York: Academic Press.

Inaba T, Matsuoka S, Kawate N, Mori J \& Torii R 1994 Developmental changes in testicular luteinising hormone receptors and androgens in the dog. Research in Veterinary Science 57 305-309.

Jegou B, de Gac F, Irby DC \& de Krester DM 1983 Studies on seminiferous tubule fluid production in the adult rat: effect of hypophysectomy and treatment with $\mathrm{FSH}, \mathrm{LH}$ and testosterone. International Journal of Andrology 6 249-260.

Killian GJ \& Amann RP 1972 Reproductive capacity of dairy bulls. IX. Changes in reproductive organs weights and semen characteristics of Holstein bulls during the first 30 weeks after puberty. Journal of Dairy Science 551631.

Lunstra DD, Ford JJ \& Echterncamp SE 1978 Puberty in bulls: hormone concentration, growth, testicular development, sperm production and sexual aggressiveness in bulls of different breeds. Journal of Animal Science 46 1054-1062.

McCarthy MS, Convey EM \& Hafs HD 1979 Serum hormone patterns associated with growth and sexual development in bulls. Journal of Animal Science 49 1012-1020.

Means AR, Fakunding JL, Huckin C, Tindall DJ \& Vitale R 1976 Follicle stimulating hormone, the Sertoli cell and spermatogenesis. Recent Progress in Hormone Research 32 477-527.

Mendis-Handagama SM \& Ariyaratne HB 2001 Differentiation of the adult Leydig cell population in the postnatal testis. Biology of Reproduction 65 660-671.

Merriam GR \& Wachter KW 1982 Algorithms for the study of episodic hormone secretion. American Journal of Physiology 243 E310-E318.

Munson PJ \& Rodbard D 1980 Ligand: a versatile computerized approach for characterization of ligand-binding systems. Analytical Biochemistry 107 220-239.

Orth JM 1984 The role of follicle stimulating hormone in controlling Sertoli cell proliferation of testes of fetal rats. Endocrinology 103 46-53.

Pearson OJ \& Tubbes PK 1967 Carnitine and derivatives in rat tissues. Biochemistry 105 953-963.
Purvis K, Calandra R, Naess O, Attramadal A, Torjesen PA \& Hansson V 1977 Do androgens increase Leydigcell sensitivity to luteinising hormone. Nature 265 169-170.

Rawlings NC \& Cook SJ 1986 Plasma concentration of testosterone, androstenedione, dihydrotestosterone, $5 \alpha$-androsterone in bull calves: response to hCG. Canadian Journal of Animal Science $\mathbf{6 6}$ 975-982.

Rawlings NC \& Evans ACO 1995 Androgen feedback during the early rise in LH secretion in bull calves. Journal of Endocrinology 145 243-249.

Rawlings NC, Hafs HD \& Swanson LV 1972 Testicular and blood plasma androgens in Holstein bulls from birth through puberty. Journal of Animal Science 34 435-440.

Rawlings NC, Fletcher PW, Henricks DM \& Hill JR 1978 Plasma luteinizing hormone $(\mathrm{LH})$ and testosterone levels during sexual maturation in beef bull calves. Biology of Reproduction 19 $1108-1112$.

Sairam MR 1978 Studies on pituitary follitropin. IV. A conformation specific radioimmunoassay for the ovine hormone. Endocrine Research Communications 5 279-291.

Secchiari P, Martorana F, Pellegrini S \& Luisi M 1976 Variation of plasma testosterone in developing Friesian bulls. Journal of Animal Science 42 405-409.

Shan L \& Hardy MP 1992 Developmental changes in levels of luteinizing hormone receptor and androgen receptor in rat Leydig cells. Endocrinology 131 1107-1114.

Shanbacher BD 1979 Relationship of in vitro gonadotropin binding to bovine testes and the onset of spermatogenesis. Journal of Animal Science 48 591-597.

Sundby A, Andersen D, Purvis K \& Hansson V 1984 Testicular gonadotropin receptors, testicular testosterone, dihydrotestosterone and androstenedione in the developing bull. Archives of Andrology 12 59-64.

Tabone E, Benahmed M, Reventos J \& Saez JM 1984 Interactions between immature porcine Leydig and Sertoli cells in vitro. An ultrastructural and biochemical study. Cell and Tissue Research 237 357-362.

Wise ME, Rodriguez RE \& Kelly CM 1987 Gonadal regulation of LH secretion in prepubertal bull calves. Domestic Animal Endocrinology 4 175-181.

Wolf FR, Almquist JO \& Hale EB 1965 Pubertal behaviour and pubertal characteristics of beef bulls on high nutrition allowance. Journal of Animal Science 24 761-765.

Yarney TA \& Sanford LM 1989 Pubertal changes in the secretion of gonadotropic hormones, testicular gonadotropic receptors and testicular function in the ram. Domestic Animal Endocrinology 6 219-229.

Yarney TA \& Sairam MR 1991 Differences in properties of the sheep testicular LH and FSH receptors. Journal of Molecular Endocrinology 6 291-297.

Yarney TA, Sanford LM \& Sairam MR 1988 Sheep testicular gonadotropin binding sites: characterization and changes with surgical shortening of the scrotum. Canadian Journal of Physiology and Pharmacology 66 1319-1327.

Received 22 April 2005

First decision 27 June 2005

Revised manuscript received 19 May 2006

Accepted 1 June 2006 